\title{
Wear Assessment of Sliding Sleeves in a Single-Stage Cycloidal Drive
}

\author{
Wojciech Żurowski', Krzysztof Olejarczyk' ${ }^{1}$ Renata Zaręba ${ }^{1 *}$ \\ 1 Kazimierz Pulaski University of Technology and Humanities in Radom, ul. Stasieckiego 54, 26-600 Radom, \\ Poland \\ * Corresponding author's e-mail: renata.nowa78@wp.pl
}

\begin{abstract}
In the paper, the issue of sliding sleeves wear in a cycloidal transmission was addressed. The working model of a cycloidal drive was constructed and tested in the special rig, and its sleeves underwent detailed analysis afterwards. The sleeves were produced by the sintering technique out of Selfoil bronze with self-lubricating properties. In particular, their surface appearance, weight loss and dimensional changes were assessed; as additionally, the chemical content of the gearbox oil was analyzed. The differences in the sleeves wear were pointed out, related to their positions in the transmission.
\end{abstract}

Keywords: single-stage cycloidal drive, wear, sliding sleeves, synthetic oil

\section{INTRODUCTION}

Cycloidal drives are often applied in many machines and devices because of their numerous benefits, such as high-ratio speed reduction, highly efficient torque delivery, compact physical structure a well as high reliability and durability [1]. Typically, they are used in the case of high loads, variable rotational speeds and alternating directions of rotations. It is common to apply sliding sleeves in the case of very high loads and speeds, where low noise is required [2]. In the present study, the performance of the sleeves made by Ames company was examined [3] in a standard single-stage tooth-to-pin-contact cycloidal drive shown in the Fig. 1.

Its operation principle is as follows: the input drive (1) introduces a torque which rotates the cycloidal discs (3) in cooperation with outer pins (4). The latter are fixed in the housing (2). The torque is then transmitted to the inner pins of the output shaft (6). The sliding sleeves of the inner pins are the most worn parts of the transmission, so they underwent a thorough analysis. The sleeves were produced with a sintering technology out of Selfoil bronze with self-lubricating properties and were impregnated with the $75 \mathrm{~W}-90$ class synthetic oil.

The most important features of the examined sleeves are listed nelow:

- very low noise,

- dynamic load up to $10 \mathrm{MPa}\left(100 \mathrm{~kg} / \mathrm{cm}^{2}\right)$,

- linear speed up to $5 \mathrm{~m} / \mathrm{s}$ (rotational 30,000 rpm),

- working temperature between $-20^{\circ} \mathrm{C}$ and $+120^{\circ} \mathrm{C}$.

Abrasive wear and contact fatigue pitting are subject of many studies, since they are the most common wear mechanisms in lubricated gear systems [4]. The wear of the responsible detail is dependent on the material quality [5] and its microstructure [6] and various surface modifications can be applied to improve wear resistance [7]. However, there are few papers dedicated to the specific wear of sliding sleeves in cycloidal drives. Researchers mainly focus on the following issues:

- kinematic error analysis and tolerance allocation [8],

- new modifications of the transmission parts [9],

- dynamic performance of modified geometrical design [10], 


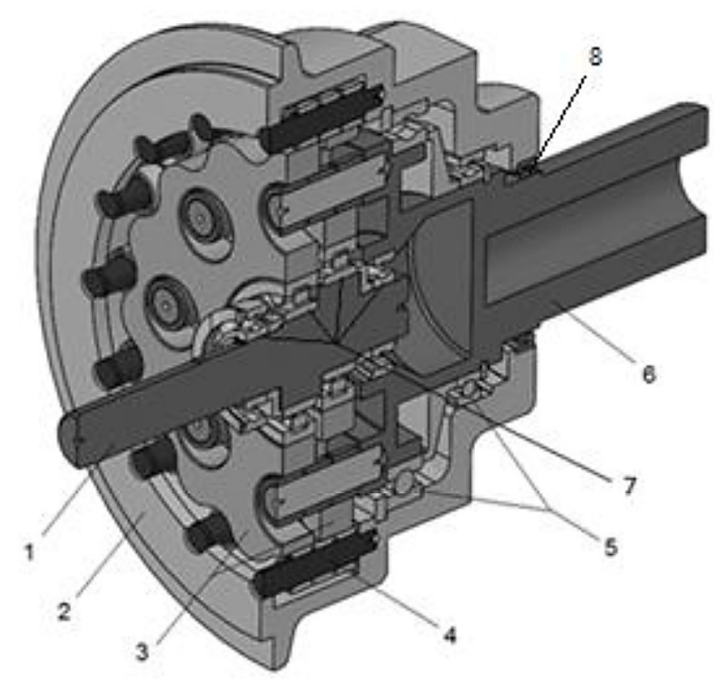

Fig. 1. Cycloidal drive: 1 - input shaft, 2 - housing, 3 - cycloidal discs, 4 - outer pins with sliding sleeves, 5 - bearings of the output shaft, 6 - output shaft with inner pins and sliding sleeves, 7 - eccentric bearings of the input shaft, 8 - sealing of the output shaft [2]

- optimal oil level, lubricator sorts and their impact on the efficiency of the cycloidal transmission, and efficiency calculations considering exploitation and maintenance $[9,11]$,

- geometry of the discs and contact forces distribution from the perspective of theoretical efficiency [12].

In one report, the author investigated the stresses distribution in the rolling elements of cycloidal drive, and noticed the pitting of the sleeves, which he attributed to the vibrations [13]. Another researcher proposed an experimental rig aimed at the analysis of cycloidal drive durability [14]. However, the issue of exploitation characteristics of the sliding sleeves in context of their durability in the papers published so far, was not addressed properly.

\section{TEST RIG AND EQUIPMENT}

For the testing purpose, a prototype transmission was prepared at the Mechanical Faculty of the Kazimierz Pulaski University of Technology and Humanities in Radom. It was placed in the test rig presented in the Fig. 2. Its open construction and data acquisition system based on National Instruments software enable to perform tests on different types of transmissions.

The prototype cycloidal drive was made with ratio $i=15$ and lubricated with the $75 \mathrm{~W}$ 90 synthetic oil. The torque measurement is performed by two devices DATAFLEX 16/10 and DATAFLEX 42/200, installed in input and output of the transmission, respectively. These devices can also provide the information on the respective rotational input and output speeds.

The test rig is equipped with TP 371K-4-50-2000 thermocouples made by Czaki company, employed in order to monitor the temperature in different places of the object. Two of them are installed in the tested prototype transmission, so that the oil temperature can be measured. The other two thermocouples are movable, installed on the magnets, so that they can be placed in any area of the test rig. In the present studies, they were placed to monitor the temperature of the cycloidal drive housing.

Additionally, the test rig is equipped with a tachometer. It can measure the rotational speed independently, e.g. for the purpose of synchronic torque measurement as a function of shaft rotational angle, and its signal can be used as a trigger.

Further elements of the test rig measurement system are the single-axis accelerometers with magnetic tips. They can measure vibrations either independently or in cooperation with a tachometer. The motors are the main devices in the test rig, so that the whole system can be driven and

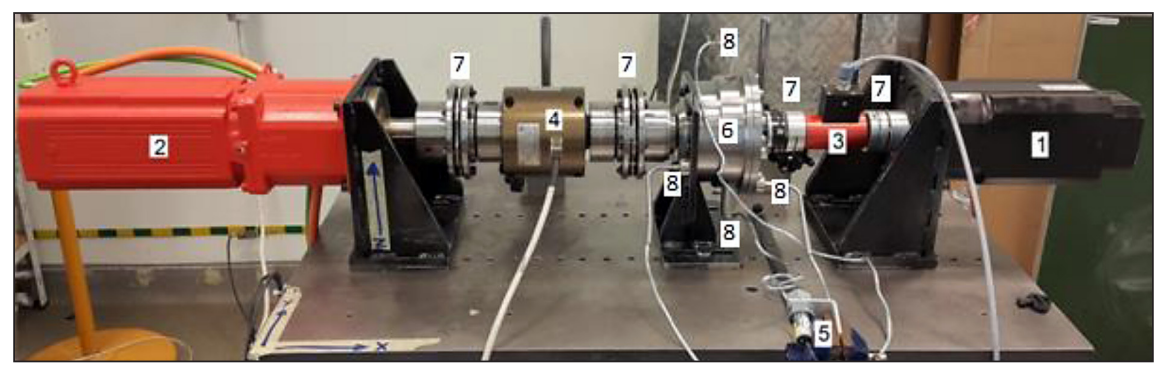

Fig. 2. Test rig: 1- motor No. 1 (drive), 2 - motor No. 2 (load), 3 -torque measurement in the transmission input (data acquisition: $\mathrm{n} 1$ - input speed, T1 - input torque), 4 - torque measurement in the transmission output (data acquisition: $\mathrm{n} 2$ - output speed, T2 - output torque), 5 - tachometer, 6 - cycloidal transmission, 7 - coupling, 8 - thermocouples [11] 
loaded in controlled way in a wide range of values $[15,16,17]$. The working cycle of the test rig is presented in Fig. 3, where the input rotational speed is $\mathrm{n} 1=4250 \mathrm{rpm}$, load $\mathrm{T} 2=30 \mathrm{Nm}$, and the time periods $\mathrm{t} 1-\mathrm{t} 9$ [s] correspond to the particular stages of the work. In the frames of one cycle, speed, load and work direction remain the same, but they can be changed in the next cycle.

The test was performed in the following conditions:

- temperature in the laboratory $22^{\circ} \mathrm{C}$,

- number of working cycles 100 cycles,

- degree of gearbox filling with oil 55\%,

- initial temperature of the oil $25^{\circ} \mathrm{C}$,

- duration of one working cycle 230s,

- time period for the average efficiency calculation $\Delta t=5 \mathrm{~s}$.

After completing 100 cycles, the test rig was turned off, the gearbox was disassembled and the sliding sleeves were measured.

\section{EXPERIMENTAL PART}

\section{Measurements of the outer diameters of sliding sleeves}

The outer diameters were measured with the dial indicator passometer made by SHUTcompany. This sort of measurement provided the comparative results related to the dimensions of setting master. Its technical parameters were as follows:

- measurement range of passameter 0-25 mm,

- measurement range of dial indicator $+/-0.04 \mathrm{~mm}$ - max. tolerance range,

- resolution of the dial indicator $0.001 \mathrm{~mm}$,
- passameter accuracy +/- $0.003 \mathrm{~mm}$.

- The sliding sleeves were made in the following dimensions: length $h=10 \mathrm{~mm}$, outer diameter

$d_{z}=14_{+28}^{+46} \mathrm{~mm}$, inner diameter $d_{w}=10_{+5}^{+20} \mathrm{~mm}$.

The examined sleeves were numbered from

1 to 7 , so that the working position of each

sleeve was identified, as it is seen in Fig. 4.

The sleeves No. 1, 3, and 4 were placed on the free tips of the inner pins, while sleeves 2 and 6 were close to the outer pins in the output shaft. As it will be demonstrated below, position in the transmission played key role in the wear of each particular sleeve.

In Fig. 4 it can also be distinguished that three areas can be treated differently on each sleeve: left area, middle area and right area. It was found that even in the new sleeve, there were some differences between the dimensions in these areas, e.g. $14.032,14.036$ and $14.035 \mathrm{~mm}$, respectively. However, the diameters of the worn sleeve in these areas appeared to be much more differentiated. Figure 5 shows the areas where the sleeves were measured, and Table 1 contains the results of the measurements.

Table 1 shows that the outer diameter of each sleeve did not change steadily, but the left area tended to be deformed more than the middle and the right ones. In some cases, the difference of diameters in different areas of the same sleeve was as large as $0.3 \mathrm{~mm}$. It should be noted also that the left area of sleeves No. 1, 2, 6 and 7 performed the largest deformation, which can be attributed to the one-sided fixation of the pin to the shaft shown in Fig. 4. This sort of fixation caused unsteady loads on the pins and on the sleeves, and subsequently unsteady deformation of the sliding elements. In addition, the loads in cycloidal transmission bearings are influenced by the rotational periods of output flange and crankshafts [18].

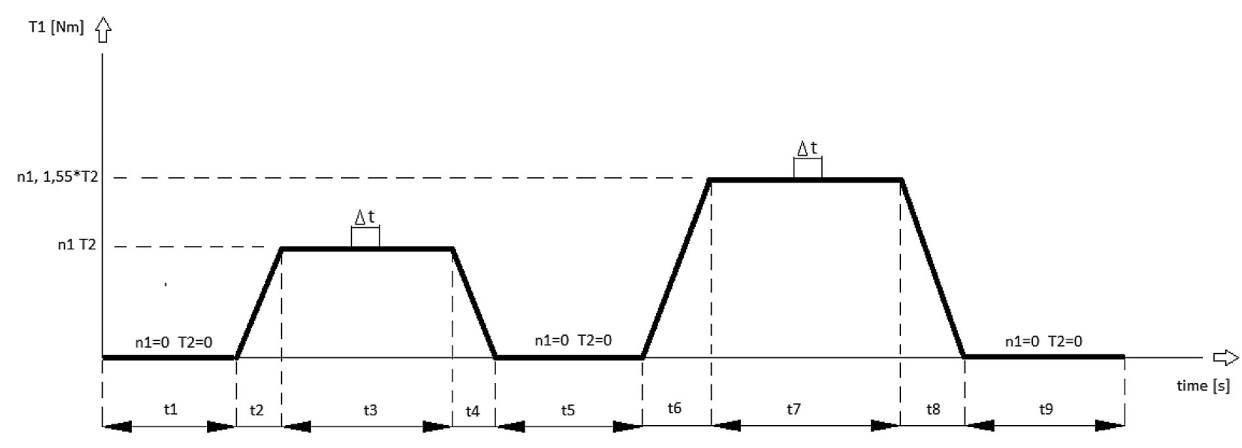

Fig. 3. General structure of the working cycle 


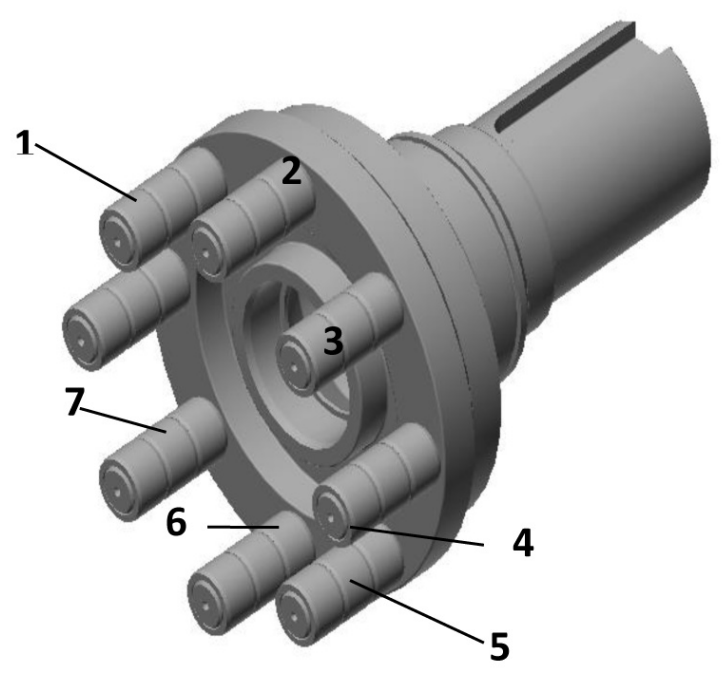

Fig.4. Examined sleeves placed on the outer pins of output shaft

\section{Measurements of inner diameters of the sliding sleeves}

The inner diameters of the sleeves were measured using the comparative method with a MET-00005 bore gauge equipped with dial indicator. The measurement range of this device was 10-18 $\mathrm{mm}$, and accuracy $0.01 \mathrm{~mm}$. The unused sleeve fabricated within the assumed tolerances had almost negligible differences between diameters in the left, middle and right areas. For example, one of the sleeves had respective measurement results of 9.95, 9.98 and $9.96 \mathrm{~mm}$. However, as it was demonstrated, the used sleeves caused a substantial increase of the inner diameters with notable differences. The measurement results are collected in the Table 2.
It is noteworthy that some sleeves were worn more on the left than on the right, namely $1,4,5$, while others lost more material in the right area than in the left one, namely 2, 6 and 7. The sleeve No. 3 revealed almost steady wear along all its length. However, the generally unsteady distribution of material losses demonstrated that the changing loads tend to cause different wear in different areas of the sleeve.

\section{Measurement of sleeves mass}

The mass of the used sleeves was measured with the accuracy of $0.001 \mathrm{~g}$. It is noteworthy that the masses of different sleeves were almost the same, ranging $\pm 0.002 \mathrm{~g}$ from average mass $5.062 \mathrm{~g}$. The results of weighing are presented in Table 3 and graphically in Fig. 6.

The results presented in Table 3 and Fig. 6 clearly indicate unequal mass reduction that can be attributed to the geometrical or dimensional inaccuracy of different elements of the cycloidal transmission. Some correlation between the position of each pin (inner and outer) related to the discs, and the corresponding sleeve wear can be observed. Even small positioning errors can increase additional loads and subsequent unsteady wear and tear of the sleeves. Since the inner pins are loaded heavier than the outer ones, the respective sleeves revealed a higher loss of the worn material.

\section{Wear assessment of the sleeves surfaces}

The visual assessment of the wear was performed with the stereoscopic microscope made by OPTA-TECH. The photomicrographs of the surfaces are shown in Fig. 7.

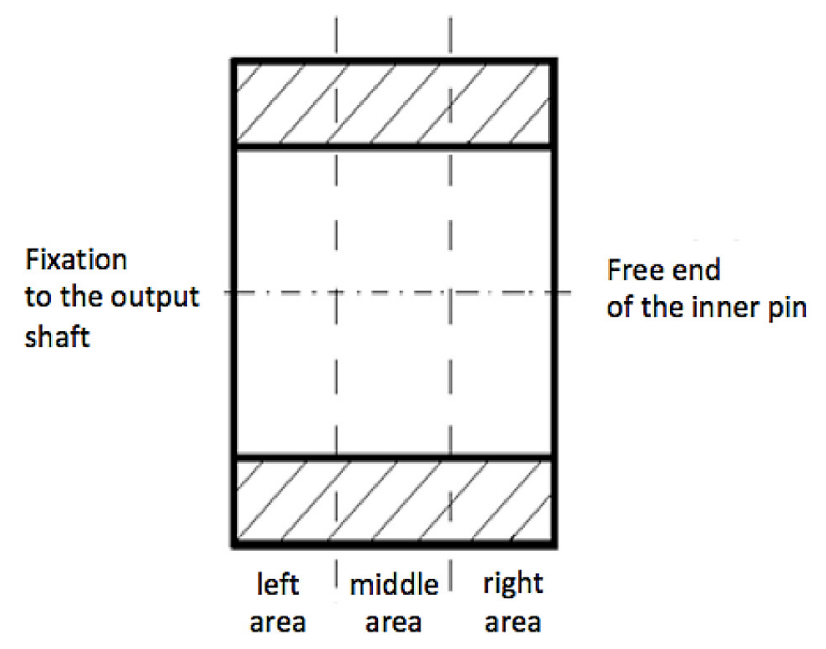

Fig. 5. Three areas of the sleeve, where diameters were measured 
Table 1. Results of the measurements of outer diameters of sliding sleeves

\begin{tabular}{|c|c|c|c|}
\hline $\begin{array}{c}\text { Sleeve } \\
\text { number }\end{array}$ & $\begin{array}{c}\text { Left } \\
\text { area [mm] }\end{array}$ & $\begin{array}{c}\text { Middle } \\
\text { area [mm] }\end{array}$ & $\begin{array}{c}\text { Right } \\
\text { area [mm] }\end{array}$ \\
\hline 1 & 14.400 & 14.270 & 14.140 \\
\hline 2 & 14.700 & 14.660 & 14.450 \\
\hline 3 & 14.070 & 14.010 & 14.170 \\
\hline 4 & 14.040 & 13.800 & 13.870 \\
\hline 5 & 14.270 & 14.250 & 14.150 \\
\hline 6 & 14.400 & 14.370 & 14.340 \\
\hline 7 & 14.850 & 14.600 & 14.520 \\
\hline
\end{tabular}

Table 3. Results of mass measurement of used sleeves

\begin{tabular}{|l|l|}
\hline Sleeve number & Mass[g] \\
\hline 1 & 5.019 \\
\hline 2 & 4.962 \\
\hline 3 & 5.022 \\
\hline 4 & 5.007 \\
\hline 5 & 5.021 \\
\hline 6 & 4.993 \\
\hline 7 & 4.977 \\
\hline
\end{tabular}

Figure 7 demonstrates that cyclic loads resulted in the fatigue of the surface layer, and in the presence of oil, pitting of microscopic crumbling took place. Fatigue caused microcracks on the surface, which were subsequently pierced open by the pressured lubricant. Further crack propagation took place to form wear particles torn by the oil and stretching stresses in the contact area. These phenomena are clearly seen, especially in the case of sleeves No. 2, 6 and 7 due to their positions in the transmission. The inner sliding sleeves underwent the highest degree of wear because they were placed close to the input shaft and were subject to the rolling friction with sliding, as
Table 2. Inner diameters of the used sleeves

\begin{tabular}{|c|c|c|c|}
\hline $\begin{array}{c}\text { Sleeve } \\
\text { number }\end{array}$ & $\begin{array}{c}\text { Left } \\
\text { area [mm] }\end{array}$ & $\begin{array}{c}\text { Middle } \\
\text { area [mm] }\end{array}$ & $\begin{array}{c}\text { Right } \\
\text { area [mm] }\end{array}$ \\
\hline 1 & 10.31 & 10.27 & 10.14 \\
\hline 2 & 10.40 & 10.50 & 10.70 \\
\hline 3 & 10.20 & 10.18 & 10.20 \\
\hline 4 & 10.18 & 10.15 & 10.10 \\
\hline 5 & 10.30 & 10.20 & 10.10 \\
\hline 6 & 10.16 & 10.25 & 10.32 \\
\hline 7 & 10.15 & 10.21 & 10.25 \\
\hline
\end{tabular}

it can be seen in Fig. 4. Thus, the highest inner stresses took place in the sleeves No. 2, 6 and 7.

Inside the surface layer, cyclic loads caused inner stresses that subsequently had impact on the sleeve microstructure. Sliding friction caused deformations in the material structure and increased wear. The deformed surface layer led to the occurrence of the subsurface cracks and spalling.

\section{ANALYSIS OF CHEMICAL CONTENT OF THE OIL}

Analysis of the oil content after tests was performed using the energy dispersive X-ray spectrometer. The method of X-ray fluorescence imaging (XRF) was applied for qualitative and quantitative assessment of the substances content in the sample. The XRF measurement enables to reveal various elements from ppm concentration up to $100 \%$ weight content. In the present research, it was important to conduct the analysis of the oil API GL-5 with viscosity 75W90 after the lubricating process of the cycloidal transmission test. The results are presented in Table 4.

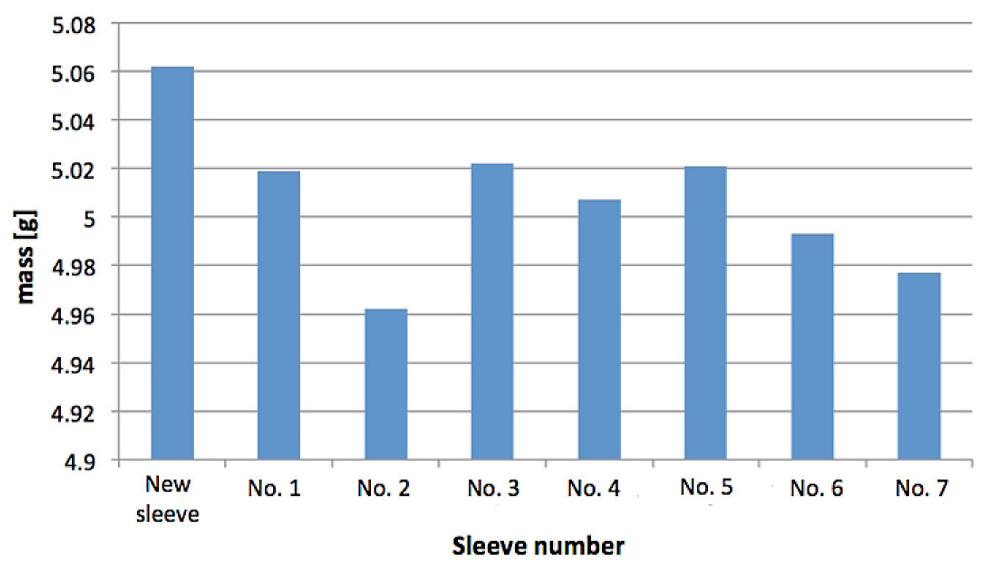

Fig. 6. Masses of the sleeves after tests 

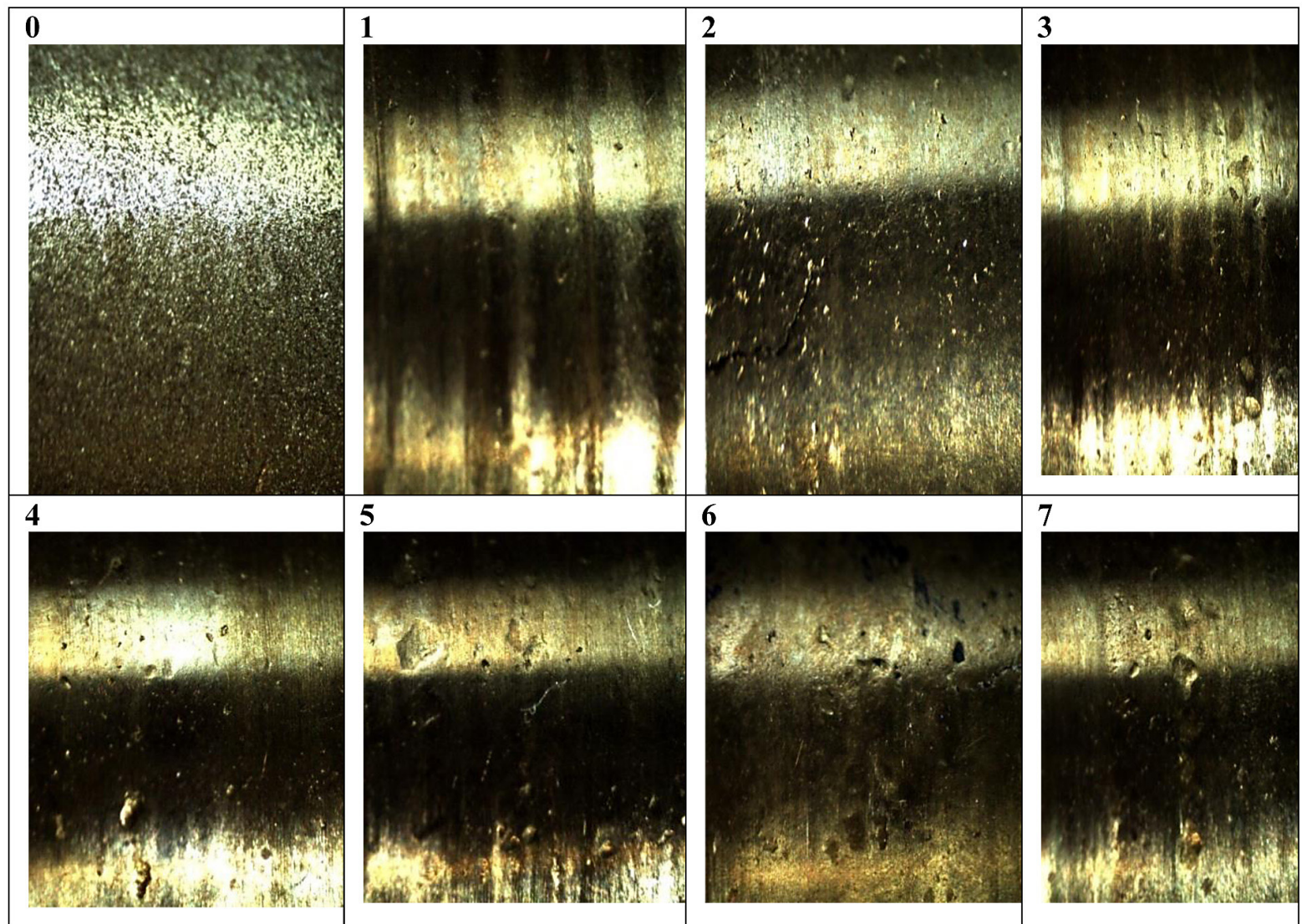

Fig. 7. Photomicrographs of the sleeves surfaces before and after the tests: 0 - example of the new sleeve surface; $1,3,4$, and 5 - sleeves placed on the inner pins rather far from the input shaft; 2, 6, and 7 - sleeves placed on the outer pins close to the input shaft

Typically, there are high concentrations of $\mathrm{S}, \mathrm{Cu}, \mathrm{Zn}, \mathrm{P}$ and $\mathrm{Mg}$ in the oil, with very small amounts of $\mathrm{Cl}, \mathrm{Cr}, \mathrm{Ni}$ and $\mathrm{Pb}$. The elements $\mathrm{Si}$ and $\mathrm{Mg}$ are from improving additions to the oil, while $\mathrm{Cu}$ and $\mathrm{Pb}$ are obviously the elements

Table 4. Content of elements in the lubricating oil

\begin{tabular}{|l|c|c|}
\hline \multicolumn{1}{|c|}{ Element } & $\begin{array}{c}\text { Oil before } \\
\text { test [ppm] }\end{array}$ & $\begin{array}{c}\text { Exploited } \\
\text { oil [ppm] }\end{array}$ \\
\hline Chlorine $-\mathrm{Cl}$ & 0.1 & 0.1 \\
\hline Sulfur $-\mathrm{S}$ & 18602.8 & 11986.9 \\
\hline Phosphorus $-\mathrm{P}$ & 1616.0 & 914.4 \\
\hline Molybdenum - Mb & 6.0 & 12.9 \\
\hline Zinc $-\mathrm{Zn}$ & 1.2 & 359.1 \\
\hline Bar $-\mathrm{Ba}$ & 2.0 & 80.4 \\
\hline Calcium $-\mathrm{Ca}$ & 9.3 & 10.6 \\
\hline Silicon $-\mathrm{Si}$ & 26.1 & 5.3 \\
\hline Magnesium $-\mathrm{Mg}$ & 1352.4 & 718.7 \\
\hline Copper $-\mathrm{Cu}$ & 0.1 & 7931.1 \\
\hline Iron $-\mathrm{Fe}$ & 0.1 & 80.6 \\
\hline Chrome $-\mathrm{Cr}$ & 0.1 & 0.1 \\
\hline Nickel $-\mathrm{Ni}$ & 0.1 & 0.1 \\
\hline Aluminum $-\mathrm{Al}$ & 0.1 & 10.0 \\
\hline Lead $-\mathrm{Pb}$ & 0.1 & 0.1 \\
\hline
\end{tabular}

removed from the worn material of transmission details made out of bronze. In the present studies, the copper concentration increased almost 80,000 times, while lead remained at the same level after tests as before. A substantial increase in the concentration was also exhibited by iron (800 times), molybdenum (2 times), zinc (more than 300 times), bar (40 times), and aluminum (100 times). These phenomena may have contributed to the wear processes in the cycloidal transmission.

The purpose of the chemical content analysis was to assess the wear of the sleeves, so that the lubricating characteristics of the oil can be omitted. Publications indicate that the sulfur compounds provide anti-wear performance of the oil at high rotational speeds and rather low loads, while the phosphorus compounds protect the material at high loads and slow speeds. The oils with the abovementioned additions are recommended in both splash and pressure lubricating systems in the closed type transmissions, especially where high loads, high rotational speeds and respectively fast sliding of the contact surfaces are expected $[1,15,16,19,20]$. 


\section{CONCLUSIONS}

The tests were aimed at assessing the wear of sliding sleeves in the cycloidal transmission. For that purpose, the dimensions and masses of the sleeves were measured, and chemical content of the lubricating oil was analyzed. The microscopic surface analysis confirmed that fatigue and pitting took place in the case of some sleeves, especially those placed on inner pins, close to the input shaft. The micrographs demonstrated different wear character of particular sleeves dependent on their positions in the transmission, which stayed in conformity with mass and diameter measurements. The wear particles were removed from the surface layer in different ways, because of different loads and inner stresses in the sleeves.

The chemical analysis with energy dispersive X-ray spectrometer revealed high concentrations of some elements in the oil, and above all a substantial increase in the concentration of wear products after the tests, especially copper and iron. Further studies will be directed on the methods of wear-resistance improvement of the sliding elements in cycloidal transmission.

\section{Acknowledgements}

The test rig was prepared in the frames of international project conducted by UTH Radom in cooperation with Airbus Helicopters (No. IPAH7409N).

\section{REFERENCES}

1. Kumar N., Kosse V., Oloyede A. A new method to estimate effective elastic torsional compliance of single-stage Cycloidal drives. Mechanism and Machine Theory, 105, 2016, 185-198.

2. Olejarczyk K., Wikło M., Kołodziejczyk K., Król K., Nowak R. Experimentalimpactstudies of the applicationmineraloil and syntheticoil on the efficiency of the single-gearcycloidal - Eksperymentalne badania wpływu zastosowania oleju na bazie mineralnej i syntetycznej na sprawność jednostopniowej przekładni cykloidalnej. Tribologia, 1, 2017, 67-73.

3. Krupowies J. Analiza zmian właściwości olejów smarowych użytkowanych w przekładni napędu głównego statków. Problemy eksploatacji, 4, 2007.

4. Feng P., Borghesani P., Chang H., Smith W. A., Randall R.B., Peng Z. Monitoring gearsurfacedegradationusingcyclostationarity of acousticemission. Mechanical Systems and Signal Processing 131, 2019, 199-221.

5. Siemiątkowski Z., Gzik-Szumiata M., Szumiata T.,
Rucki M., Martynowski R. Metallurgical quality evaluation of the wind turbine main shaft $42 \mathrm{CrMo} 4$ steel: microscopic and Mössbauer studies. Nukleonika 62(2), 2017, 171-176.

6. Rai P.K., Shekhar S., Yagi K., Ameyama K., Mondal K. Frettingwearmechanism for harmonic, non-harmonic and conventional 316L stainless steels. Wear 424-425, 2019, 23-32.

7. Morozow D., Narojczyk J., Rucki M., Lavrynenko S. Wear Resistance of the Cermet Cutting Tools After Aluminum $(\mathrm{Al}+)$ and Nitrogen $(\mathrm{N}+)$ Ion Implantation. Advances in Materials Science 18(2), 2018, 92-99.

8. Lin K.-Sh., Chan K.-Y., Lee J.-J. Kinematic error analysis and tolerance allocation of cycloidalgearreducers.Mechanism and Machine Theory 124, 2018, 73-91.

9. Renzh.-Y., Maosh.-M., Guow.-Ch., Guozh. Tooth modification and dynamic performance of the cycloidal drive. Mechanical Systems and Signal Processing 85, 2017, 857-866.

10. Hsieh Ch.-F. Traditional versus improved designs for cycloidalspeedreducers with a small tooth difference: The effect on dynamics. Mechanism and Machine Theory 86, 2015, 15-35.

11. Olejarczyk K., Wikło M., Król K., Kołodziejczyk $\mathrm{K}$. Obliczenia teoretyczne oraz pomiary stanowiskowe sprawności przekładni cykloidalnej. Modelowanie Inżynierskie Tom: 33, Zeszyt, 64, 2017, 74-80.

12. Olejarczyk K., Wikło M., Król K., Kołodziejczyk $\mathrm{K}$. Wyznaczania optymalnego poziomu oleju $\mathrm{w}$ oparciu o temperaturowe i sprawnościowe kryteria dla prototypowej przekładni cykloidalnej. Autobusy: technika, eksploatacja, systemy transportowe, 6, 2017, 966-999.

13. Chmurawa M. Cycloidal gears with tooth modification (in Polish). Silesian Technical University, Zeszyty naukowe, 1547, 2002.

14. Warda B. Stanowisko do badania trwałości zazębienia obiegowej przekładni cykloidalnej, Tribologia 6, 2006, 131-140.

15. Baczewski K. Tribologia i płyny eksploatacyjne. WAT, Warszawa 1994.

16. Lawrowski Z. Tribologia Tarcie, Zużywanie i Ścieranie. PWN, Wrocław 2008.

17. Self-lubricating sintered bearings, http://www. ames-sintering.com/products/self-lubricating-bearings/selfoil/ [Access: 34.08.2019].

18. Xu L.X., Chen B.K., Li Ch.Y. Dynamic modelling and contact analysis of bearing-cycloid-pinwheel transmission mechanisms used in joint rotate vector reducers, Mechanism and Machine Theory 137, 2019, 432-458,

19. Hebda M. and Wachal A. Trybologia. WNT, Warszawa 1980.

20. Płaza S., Margielewski L., Celichowski G. Wstęp do tribologii i tribochemii. Łódź 2005. 